\title{
Typology and the formal modelling of syncretism ${ }^{\star}$ Matthew Baerman Surrey Morphology Group, University of Surrey
}

\section{Introduction}

Inflectional syncretism is the expression of two or more distinct morphosyntactic feature values by a single form, ${ }^{1}$ as illustrated in the Macedonian example in (1), where 2SG and 3SG are identical in both of the past tenses, though not in the present. (Throughout this paper syncretized values are represented by ' $\%$. Thus, we can represent the Macedonian pattern as '2 $\mathrm{SG} / 3 \mathrm{SG}$ ' syncretism.)

Macedonian 'fall' (discussed in Stump 1993)

\begin{tabular}{llll}
\hline & present & aorist & imperfect \\
\hline 1SG & padnam & padnav & padev \\
2SG & padneš & padna & $\begin{array}{l}\text { padneše } \\
\text { padneše }\end{array}$ \\
3SG & padne & padna & padnevme \\
1PL & padneme & padnavme & pade \\
2PL & padnete & padnavte & padnevte \\
3PL & padnat & padnaa & padnea
\end{tabular}

The interpretation of such examples remains a disputed question in morphological theory. On the one hand, the collapse of these two values may be ascribed to some underlying affinity, on the assumption that they constitute a natural class. On the other hand, it may be treated as a purely formal relationship, arbitrarily stipulated in the morphology. It is probably fair to say that most scholars who have written on the topic have favoured the former approach, viewing syncretism as a reflection of the internal structure of morphosyntactic features. The pioneering works in this vein were Jakobson's $(1936,1958)$ studies of Russian nominal inflection, in which case values were broken down into semantic components in the same way phonemes may be broken down into phonological features. Syncretic forms are thus

\footnotetext{
^ Thanks for helpful comments go to Dunstan Brown, Andrew Carstairs-McCarthy, Marina Chumakina, Greville Corbett, Michael Cysouw, Martin Haspelmath, Greg Stump, the audience at the Mediterranean Meeting on Morphology in Catania (September 2003) and three anonymous referees. The research reported here was supported in part by the Economic and Social Research Council under grant number R000237939. Their support is gratefully acknowledged.

${ }^{1}$ In general, the existence of a morphosyntactic distinction is determined on a language-particular basis. For example, in (1), it is clear that second and third person singular are potentially distinct values in Macedonian, because they are associated with distinct inflectional forms in the past tenses. Further, a distinction made in one number can be extended to another, as in German, where the distinction between first and third person in the singular (ich mache 'I make' versus sie macht 'she makes') justifies the assumption that they are distinct in the plural as well, even though they are always syncretic (wir machen 'we make', sie machen 'they make'). For the purposes of the present paper, we have relaxed this morphological criterion, assuming a minimum of three person values (first, second and third) for the languages under consideration, even where inflection shows no more than two distinctions.
} 
construed as realizations of the natural classes of semantic components that make up morphosyntactic features.

On this view, it is desirable that a formal model of morphological structure be inherently restrictive, allowing some syncretic patterns to be described while banning others. Examples of this approach include Bierwisch 1967, Carstairs 1987, 1998, Noyer 1997, 1998, Bobaljik 2002, Williams 1994, Neidle 1988, Blevins 1995, Calabrese 1998, Müller (forthcoming), Lumsden 1992 and Wiese 1996. However, though various constraints on syncretism have been proposed, either explicitly or implicitly, there has been no systematic attempt to assess these claims against the evidence of more than a handful of languages. It is the goal of this paper to evaluate some plausible claims against a large corpus of examples.

The scope of the present study is restricted to subject person marking on verbs. Person has been chosen because its possible values are constrained, allowing us to make more direct comparisons across languages than other features would allow. We assume that languages which mark person distinguish at least the three values of first (exclusive and inclusive), second and third person; additional distinctions (e.g. honorific versus familiar, proximate versus obviative, and same subject versus different subject) are limited, and for the most part will not play a role in what follows. The core sample used below is a corpus of 109 genetically and geographically diverse languages which evince person syncretism on verbal subject markers (see the appendix). Additional languages are adduced as needed. We only consider syncretism at the whole word level -- that is, where the identity obtains over the entire inflected word form, and is not restricted to one morphological component. In those examples where only inflectional affixes are cited (as in §3), it can be assumed that the other components of the word are invariant. We have also tried to eliminate instances where the identity of distinct forms is transparently ascribable to a synchronically active phonological rule. ${ }^{2}$

Below we assess two predictions that have been derived from formal constraints: (i) which person values can be combined in a single form, and (ii) do patterns of syncretism reflect markedness relations between the syncretized values?

\section{$2 \quad$ Patterns of syncretism}

If syncretism reflects underlying natural classes of feature values, then we should expect to find only those values syncretized which are licensed by feature structure. In order to assess this assumption, we shall take the model of person feature structure recently proposed by Harley and Ritter (2002). The feature person is analyzed as a hierarchy of three nodes. The dominant node, Referring Expression (RE), indicates the presence of pronominal features. The second node, Participant (PARTIC), is dependent on RE. The value +PARTIC marks a discourse participant, that is, speaker or addressee, while -PARTIC is interpreted as a third person by default. The third node, Addressee (ADDR), depends on +PARTIC, and marks the addressee, namely 2nd person. -ADDR is interpreted by default as the speaker, namely 1 st person. Number is construed as a separate hierarchy.

\footnotetext{
${ }^{2}$ For example, the regular reduction of unstressed vowels leads to homophony of feminine and neuter in the past tense of Russian verbs where the endings are not stressed: neslá $\sim$ nesló 'carried.FEM NEUT' versus pisál[ $\leftrightarrow$ ] 'wrote.FEM/NEUT'. Such obvious instances are rare in our corpus, and we do not otherwise presume to distinguish between 'systematic' and 'accidental' homophony, for reasons which should be made clear by the Dhaasanac example discussed in $\$ 3.6$; also see fn. 3 for an observation on the possible pitfalls of resorting to this distinction.
} 


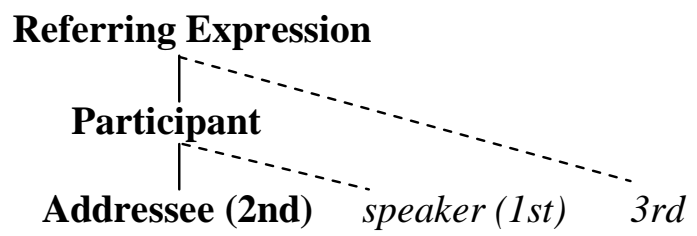

First and second person are construed as a natural class, subsumed under the node +PARTIC. Thus syncretism of first and second person is the only pattern licensed by feature structure. On a strict version of the hypothesis we are testing, this should be the only pattern we find; or, on a looser interpretation, it should predominate.

A superficial glance at the data in the appendix is not promising: not only does this pattern not predominate, no pattern does. However, we can bring some order to the apparent chaos if we distinguish between complete and partial syncretism, the results are less equivocal. By complete syncretism we mean that a given pattern is consistently found in all the paradigms in the language, while partial syncretism is restricted in scope, for example, to a particular tense or conjugation class. This is admittedly a crude division: where a language has only one set of inflectional markers, it achieves complete syncretism vacuously. Nevertheless, it proves to be a useful criterion, in that it allows some distinct patterns to emerge.

Where syncretism is complete, there is a sharp contrast between the behaviour of person in the singular versus non-singular. Complete syncretism of person solely in the singular is uncommon. Out of twenty nine examples of complete person syncretism in the sample (from twenty seven languages), only six are restricted to the singular. Of these, two come from languages where person is not distinguished in the plural, so that it is not so much the case that the syncretic pattern is restricted to the singular, but that person marking itself is restricted to the singular. In the nonsingular, $1 / 2$ and $2 / 3$ both occur in roughly equal measures, while $1 / 3$ is less common. A similar distribution is found where number is irrelevant, with examples of $1 / 2$ and of $2 / 3$ predominating.

(3) Examples of complete syncretism, by language

\begin{tabular}{c|l|l|l|}
\multicolumn{2}{c}{ singular } & \multicolumn{1}{c}{ non-singular } & \multicolumn{1}{c}{ number-neutral } \\
\cline { 2 - 4 } $1 / 3$ & Koiari*, Zoque & Aleut, German, Hindi & \\
\cline { 2 - 4 } $2 / 3$ & $\begin{array}{l}\text { Atakapa, Hindi, } \\
\text { Nivkh*, Nubian }\end{array}$ & $\begin{array}{l}\text { Amele, Kapau, Kewa, } \\
\text { Kobon, Slovene }\end{array}$ & $\begin{array}{l}\text { Chitimacha, } \\
\text { Guambiano, Kiwai, } \\
\text { Wambon }\end{array}$ \\
\cline { 2 - 4 } $1 / 2$ & & $\begin{array}{l}\text { Burarra, Dogon, } \\
\text { Manchad, Nubian, Prinmi } \\
\text { Tetun }\end{array}$ & $\begin{array}{l}\text { Hunzib, Ingush, Nez } \\
\text { Perce, Sango } \\
\text { Waskia }\end{array}$ \\
\cline { 2 - 4 } & \multicolumn{2}{|c}{ * Person distinguished in singular only. }
\end{tabular}

Thus, cross-linguistically, there seems to be a preference for syncretism of first with second person, and of second person with third, in both cases restricted to nonsingular or number-neutral contexts. Interestingly, this corresponds well with the sorts 
of patterns found in free pronouns, as shown in (4). (The sample here is based on Cysouw 2003, with other examples added informally.)

(4) Compound person values in free pronouns

\begin{tabular}{l|l|l|l|}
\multicolumn{1}{c}{ singular } & \multicolumn{1}{c}{ non-singular } & \multicolumn{2}{c|}{ number-neutral } \\
\cline { 2 - 4 } $1 / 3$ & Dakar Wolof & \\
\cline { 2 - 4 } & & Amele*, Kalam*, & Kawesqar \\
& & Kamoro, Kobon, Korafe*, & \\
& & Meyah, Mansim, Nez & \\
& & Perce*, Sango*, & \\
& & Warekena*, Wolof & \\
\cline { 2 - 4 } $1 / 2$ & Awa*, Fongbe, Slave*, & Winnebago \\
& & Yimas & \\
& &
\end{tabular}

*Examples from Cysouw (2003). Other sources: Dakar Wolof from Nussbaum et al. (1970), Fongbe from Lefebvre and Brousseau (2002), Kamoro from Voorhoeve (1975), Kawesqar in Clairis (1985), Mansim and Meyah from Reesink (2002), Winnebago from Lipkind 1945, Yimas from Foley (1991).

As with inflectional marking, nearly all the examples of combined person values in free pronouns involve $1 / 2$ and $2 / 3$ in the non-singular; none involve syncretism of singular person values alone. (Note that the evidence from number-neutral pronouns is exceedingly thin: we are aware of only two examples, the $1 / 2$ emphatic personal pronoun of the Siouan language Winnebago (Lipkind 1945: 29) and the 2/3 pronoun of the Patagonian language Kawesqar (Clairis 1985: 465); the latter is only partial, in that there are distinct possessive forms for these two persons).

These patterns cannot be derived from the model of feature structure found in Harley and Ritter (2002). First, their model licenses only 1/2 syncretism, but not 2/3. However, not only does $2 / 3$ syncretism occur, it is no less common than $1 / 2{ }^{3}$ Second, since number occupies a node separate from person, this model predicts that number will have no influence on patterns of person syncretism. .

If we choose to ascribe a semantic rationale to these patterns, it is probably significant that non-singular numbers favour syncretism, since this is precisely the context where there may be referential overlap, and hence ambiguity. Thus, in a language without an inclusive exclusive distinction, first person plural may or may not include the addressee, so blurring the distinction between first and second person.

\footnotetext{
${ }^{3}$ The aim of Harley and Ritter (2002) is specifically to account for the values of free pronouns, not the inflectional marking of person (though it does not appear that their model would distinguish between the two). They predict that if a language does display a $2 / 3$ or $1 / 2$ pronoun, that this is a result of accidental homophony, and will be disambiguated by verb agreement (p. 513, note 42). This prediction is contradicted by Amele, Kobon (dual only) and Nez Perce. Even if this prediction were true, it is curious that accidental homophony would be more frequent than systematic syncretism, which the data in (4) suggest.
} 
Likewise, second person plural may or may not be construed as including some nonaddressees, so blurring the distinction between second and third person. Nevertheless, there are reasons to be cautious about overemphasizing the semantic naturalness of such syncretic combinations, which are especially apparent when one considers the behaviour of the first person inclusive. Since semantically it overlaps with first and second person, we should expect syncretism with those two persons. While this does occur, instances of 1INCL/1EXCL syncretism are far more frequent than 1INCL/2, which is not readily accounted for if semantic overlap is deemed to license the syncretism; signficantly, $1 \mathrm{INCL} / 2$ syncretism is no more frequent than $1 \mathrm{INCL} / 3$, which cannot be accounted for by the notion of semantic overlap (Cysouw forthcoming a). An example of such an 'unnatural' pattern comes from the Austronesian language Kwamera (5), where the first inclusive is syncretic with the third person in the dual, precisely the pattern one would expect not to find. ${ }^{4}$

$$
\text { Kwamera verbal prefixes (Lindstrom and Lynch 1994: 10) }
$$

\begin{tabular}{llll}
\hline & SG & DU & PL \\
\hline $1($ EXCL $)$ & iak- & iak-rou- & iak-ha- \\
2 & ik- & ik-rou- & ik-ha- \\
3 & r- & k-rou- & ha- \\
1 INCL & ------- & k-rou- & sa-ha-
\end{tabular}

Conversely, in the Australian language Burarra (see 20 below), the first person inclusive has a distinct form, while the first person exclusive and second person are syncretic in the dual and plural. Since the first exclusive and second person are mutually exclusive, there can be no question of a semantic or functional overlap between the values of the syncretic form (see Noyer 1997: 118-31 for discussion of a similar pattern in the Mayan language Mam).

\section{Directional effects}

Directional effects occur where the syncretic form looks as if it has 'borrowed' the form of one of its component values. Stump (1993) adduces the Macedonian paradigms in (1) as an example of this. The syncretic $2 \mathrm{sG} / 3 \mathrm{SG}$ of the past tenses has the ending $-\varnothing$ in the aorist, which he identifies as a $3 \mathrm{SG}$ form on the basis of the present tense paradigm. In Stump's analysis this effect is attributed to a purely morphological device, a rule of referral, whereby the 2SG takes the form of the $3 \mathrm{SG}$ (see also Zwicky 1985, Stump 2001, Corbett and Fraser 1993). On this approach, there is no way to predict which values will provide forms, and which values will receive them. However, there are other researchers who see directional effects as a reflection of underlying markedness relationships within feature structure. On this approach, the behaviour of directional effects should be predictable. Below we will

\footnotetext{
${ }^{4}$ Note though that Kwamera has an impersonal marker $k$-, and a morphological relationship between impersonals and the first plural is known from other languages. Thus, in some Athapaskan languages, the unspecified person marker is used for the first plural (Rice 2000: 201), in Ngiti, the third person indefinite form is used for first person inclusive when preceded by a free pronoun (Kutsch Lojenga 1994), and, of course, the use of the French impersonal on for first plural is well known.
} 
examine two proposals, namely Noyer's (1998) version of impoverishment, and Carstairs-McCarthy's lexical semantic constraint on syncretism.

In impoverishment theory (Noyer 1998), it is held some feature values are marked with respect to others. Under certain language-specific conditions, marked values may be deleted, in which case they are replaced by the unmarked value for that feature. This means that wherever we see directional effects, the form which prevails should be the one associated with the unmarked value. With respect to person, it is commonly assumed that third person is the default value. This is how Bobaljik (2002) analyzes the Macedonian example above: the value 2 is deleted in the singular of the past tenses, and replaced by the default person value, namely 3 . This licenses the use of third person morphology even where second person should be expected.

Carstairs-McCarthy (1998) develops a somewhat different set of predictions concerning directional effects. The underlying principle is that inflectional meaning should be governed by the same constraints that obtain for lexical semantics, which leads to three relevant axioms, summarized below: ${ }^{5}$

A. Lexical items do not contain meanings consisting of incompatible disjuncts, e.g. *'apple OR banana'. By the same token, inflectional meaning should not contain incompatible disjuncts consisting of competing values for the same feature, e.g. *'ablative OR locative’. (Carstairs-McCarthy assumes that feature structure is flat.)

C. Lexical items may contain compatible disjuncts. For example, the different senses of climb in

(a) the boy climbed up the tree

(b) the boy climbed down the tree

(c) the snake climbed up the tree

can be reconciled by characterizing its semantics as 'go, upward OR clambering'. Sentence (b) contains only the element 'clambering' and sentence (c) only the element 'upward', but the two meanings are compatible with each other, as witnessed by sentence (a). (Carstairs-McCarthy takes this example from Jackendoff 1985.)

E. No rule can make overt reference to the unmarked value of a feature

Axioms $\mathrm{A}$ and $\mathrm{E}$ by themselves account for a subset of the phenomena allowed in Noyer's (1998) model, allowing directional effects that appear to involve the extension of the unmarked value in an unmarked context. Consider the singular person paradigm from the Chibchan language Ika, illustrated in (6). First and third person singular are syncretic in all tense paradigms except the distal past. The syncretic $1 \mathrm{SG} / 3 \mathrm{SG}$ form has no overt person-marking affix, which makes it look like the $3 \mathrm{SG}$ form of the distal past.

\footnotetext{
${ }^{5}$ There are two further axioms, but they are not of direct relevance in describing directional effects.
} 


\begin{tabular}{|c|c|c|}
\hline \multicolumn{2}{|r|}{ distal past } & elsewhere \\
\hline $1 \mathrm{SG}$ & (stem) -rua-na & (stem) \\
\hline $2 \mathrm{SG}$ & $\mathrm{n} \wp$-(stem) & $\begin{array}{l}\text { n } ९- \\
\text { (stem) }\end{array}$ \\
\hline $3 \mathrm{SG}$ & (stem) & (stem) \\
\hline
\end{tabular}

This distribution of the person markers can be accounted for by underspecification, as illustrated in (7), assuming that third person and 'elsewhere' are the unmarked values for person and tense, respectively. The ending -rua is specified as the first person distal past ending, $n \wp$ - as the second person prefix, unspecified for tense, and $\varnothing$ is the general default, unspecified for tense and person. The effect is the same as an impoverishment analysis in which the value $2 \mathrm{SG}$ was deleted, but axiom $\mathrm{E}$ imposes a further constraint. Since no overt reference can be made to unmarked values, the syncretism is predicted to occur only in the unmarked context; that is, one could not have $2 \mathrm{SG} / 3 \mathrm{SG} \varnothing$ in the distal past but not in the 'elsewhere' tenses.

$$
\begin{array}{ll}
\text { rua } & 1, \text { distal past } \\
n \wp- & 2 \\
\varnothing &
\end{array}
$$

However, axiom $\mathrm{C}$ allows for a second type of directional effect, which CarstairsMcCarthy illustrates with an example from Hungarian conjugation, shown in (8). At issue is the distribution of the 1SG affixes $-k$ and $-m$, which are isolated in (9). In the present, $-k$ marks the indefinite and $-m$ the definite, but in the past $-m$ marks both. Thus, definite and indefinite are syncretic in the past, and it looks as if the form of the definite has prevailed.

\begin{tabular}{lll}
\hline & present & past \\
\hline 1SG INDEF & vár-o-k & vár-t-a-m \\
1SG DEF & vár-o-m & vár-t-a-m
\end{tabular}

\begin{tabular}{lll}
\hline & present & past \\
\hline \multirow{2}{*}{ 1SG INDEF } & $-\mathrm{k}$ & $-\mathrm{m}$ \\
1SG DEF & $-\mathrm{m}$ & $-\mathrm{m}$ \\
\cline { 2 - 3 } & &
\end{tabular}

Carstairs-McCarthy assumes that plural and past are the marked values for number and tense, respectively. He attributes the distribution of the affixes to the rules in (10). Since the values 'past' and 'definite' can co-occur, the value of $-m$ contains a compatible disjunction; $-k$ is simply an elsewhere form.

$$
\begin{array}{ll}
-m & 1, \text { definite OR past } \\
-k & 1
\end{array}
$$

Thus, the use of disjunctive feature values yields for Hungarian a pattern which is the mirror image of that found in Ika. In Ika, the form associated with the unmarked value 
prevails in the unmarked context, while in Hungarian, the form associated with the marked value prevails in the marked context.

Thus, both Noyer (1998) and Carstairs-McCarthy (1998) predict that directional effects are constrained by markedness, but the actual predictions differ. Noyer predicts that directional effects will involve the extension of the unmarked form. Carstairs-McCarthy predicts a kind of markedness harmony: directional effects will involve either (i) the extension of the unmarked form in the unmarked context, or (ii) the extension of the marked form in the marked context.

In order to evaluate these predictions, we present below examples of directional effects in person syncretism. By necessity, this is an informal corpus. Quite simply, it constitutes all the reasonably convincing examples that we have come across; the corpus could be expanded or shrunk depending on what one considers to be a convincing example of directionality. We have limited ourselves to examples where the syncretism is realized by an overt morphological marker, rather than by a bare stem, as in the Ika example above (6). In so doing we eliminate instances which would be transparently interpretable as underspecification under practically any formal model.

Since both predictions that we propse to investigate crucially depend on markedness, we must first establish what the markedness hierarchy is between person values. Both Noyer and Carstairs-McCarthy concur that third person is the unmarked value, but the relationship between first and second person, if any, remains indeterminate. For the purposes of exposition we will assume the hierarchy implied by Harley and Ritter (2002), illustrated above in (2), where second person is marked with respect to first person. Note that only the inflectional affixes are given in the examples below; unless otherwise indicated, the stems are identical in all the forms.

\subsection{First person / third person.}

There are not many convincing examples of directionality involving these values. The Papuan language Koiari of the Trans-New Guinea phylum (11) seems to confirm the prediction that the third person form should prevail, in as much as the 1sG obligatory mood may optionally be identical to the 3SG (elsewhere, first and third person are always identical). Livonian (see below, 27) presents a diachronic example where the third person form prevailed.

(11) Koiari (Dutton 2003: 345, 351)

\begin{tabular}{lllll}
\hline & \multicolumn{2}{c}{ obligatory mood } & imperfect & perfect \\
& option 1 & option 2 & & \\
\hline \multirow{2}{*}{ 1SG } & -ahina & -ahima & -ma & -nu \\
2SG & -ihama & -ihama & -a & -nua \\
3SG & -ahima & -ahima & -ma & -nu \\
PL & -ihava & -ihava & -a & -nua
\end{tabular}

But there are also examples where the first person form seems to prevail. In the NiloSaharan language Murle (12), first person (inclusive) and third person are syncretic (in both numbers) in the subjunctive but not the perfect. In the perfect, the first person is characterized by prefixed $k$-, while the third person has no prefix. The syncretic 
form in the subjunctive has a prefixed $k$-, just as the distinct first person of the perfect. Thus, it appears as if an overtly first person element is serving for third person as well. ${ }^{6}$

(12) Murle (Lyth 1971: 83)

\begin{tabular}{|c|c|c|}
\hline & perfect & subjunctive \\
\hline $1 \mathrm{SG}$ & $\mathrm{k}-\quad-\mathrm{a} \longrightarrow$ & $\mathrm{k}-$ \\
\hline $2 \mathrm{SG}$ & $-\mathrm{u}$ & $\varnothing$ \\
\hline $3 \mathrm{SG}$ & $(- \text { un })^{7}$ & $\mathrm{k}-$ \\
\hline 1INCL PL & k- - it $\longrightarrow$ & k- - it \\
\hline 1PL & $\mathrm{k}-\quad-\mathrm{da}$ & $\mathrm{k}-\quad-\mathrm{da}$ \\
\hline $2 \mathrm{PL}$ & $-\mathrm{tu}$ & -it \\
\hline 3PL & -it & $k-\quad-i t$ \\
\hline
\end{tabular}

\subsection{Second person / third person.}

Here there are rather more clear examples of directionality than with $1 / 3$ syncretism, though the results are mixed. In some examples the third person form prevails, e.g. in Macedonian, as discussed in (1). Likewise, in the Nilo-Saharan language Nobiin (13), the 2SG appears to take the form of the 3SG in both tenses (present and past). In Dutch (14), the syncretic pattern is correlated with the position of the subject pronoun. When subject pronouns are preposed, $2 \mathrm{SG}$ takes the ending $-t$, identical to that of the $3 \mathrm{SG}$. When the subject pronoun is postposed (as occurs in questions and in subordinate clauses), only 3SG takes $-t$; thus jij kom- $t \sim$ kom je 'you're coming $\sim$ are you coming?' versus zij kom- $t \sim$ kom- $t$ zij 'she's coming $\sim$ is she coming?'.

(13) Nobiin present past (Werner 1987)

\begin{tabular}{|c|c|c|}
\hline & indicative & interrogative \\
\hline $1 \mathrm{SG}$ & -ir -is & -re \\
\hline $2 \mathrm{SG}$ & -nam -onam & $-\mathrm{i} \sim-\mathrm{o}$ \\
\hline $3 \mathrm{SG}$ & $-\mathrm{i} \sim-\mathrm{O}$ & $-\mathrm{i} \sim-\mathrm{O}$ \\
\hline $1 P L$ & -ir $\sim$-is & -ro $\sim-$-So \\
\hline $2 \mathrm{PL}$ & -rokom -sokom & -ro $\sim-$ so \\
\hline 3PL & -inna -sa & -inna -sa \\
\hline
\end{tabular}

(14) Dutch 'come'

\begin{tabular}{|c|c|c|}
\hline & $\mathrm{vb}+$ pro & pro $+\mathrm{vb}$ \\
\hline $1 \mathrm{SG}$ & $-\varnothing$ & $-\varnothing$ \\
\hline $2 \mathrm{SG}$ & $-\varnothing$ & $-\mathrm{t}$ \\
\hline $3 \mathrm{SG}$ & $-\mathrm{t} \longrightarrow$ & $-\mathrm{t}$ \\
\hline 1PL & -en & -en \\
\hline 2PL & -en & -en \\
\hline 3PL & -en & -en \\
\hline
\end{tabular}

\footnotetext{
${ }^{6}$ Note though that the related language Mursi (both members of the Surmic branch of Nilo-Saharan) has a similar pattern, in which the 3SG may have a stem alternant distinct from the others (Turton 1981: 344).

${ }^{7}$ The suffix - un is found optionally in the perfect.

${ }^{8}$ This pattern is not entirely systematic, as there is one verb which displays a stem alternation which disambiguates the 2SG and 3SG (jij heb-t 'you have' versus zij heef- $t$ ' she has'), and another verb where $2 \mathrm{SG}$ has $-t$ even though $3 \mathrm{SG}$ does not (jij ben- $t$ 'you are' versus zij is 'she is'). Historically, the 2SG form descends from the 2PL, whose ending $-t$ is cognate with the German 2PL seen in (28).
} 
Although there are examples where the third person form prevails, there are even more which favour second person. For example, in Callahuaya, a Quechuabased creole, the original second person marker $-n k i$ is sometimes found with third person; contrariwise, 3rd person $-n$ is not used for second person (Muysken 1997: 437-8). In the Bantu language Kongo (15), indicative subjects are marked by a prefix on the auxiliary, while subjunctive subject markers are prefixed to the main verb stem; note that the latter prefixes are asyllabic. The syncretic prefix $o$ - of the indicative is the same as the distinct $2 \mathrm{SG} w$ - of the subjunctive, if one factors out the difference in syllabicity. ${ }^{9}$ In Old Icelandic (16), the syncretic $2 \mathrm{SG} / 3 \mathrm{SG}$ ending -er of the present indicative is the same as the distinct $2 \mathrm{SG}$ ending found in the other tensemood paradigms. (The indicative subjunctive contrast is marked by a vowel alternation in the ending for all but 1SG and 2PL.)

Kongo (Carter and Makoondekwa 1979: 6, 9, 11, 19-21)

\begin{tabular}{|c|c|c|}
\hline & subjunctive & indicative \\
\hline $1 \mathrm{SG}$ & $\mathrm{y}-$ & i- \\
\hline $2 \mathrm{SG}$ & $\mathrm{W}-\quad \longrightarrow$ & o- \\
\hline $3 \mathrm{SG}$ & $\mathrm{k}-$ & O- \\
\hline $1 \mathrm{PL}$ & tw- & tu- \\
\hline $2 \mathrm{PL}$ & nw- & nu- \\
\hline 3PL & b- & be- \\
\hline
\end{tabular}

(16)

Old Icelandic weak verb (Noreen 1923: 353-4)

\begin{tabular}{lll}
\hline & $\begin{array}{l}\text { subjunctive, } \\
\text { preterite }\end{array}$ & present indicative \\
\hline $1 \mathrm{SG}$ & $-\mathrm{a}$ & $-\mathrm{a}$ \\
$2 \mathrm{SG}$ & $-\mathrm{er} \longrightarrow$ & $-\mathrm{ar}$ \\
$3 \mathrm{SG}$ & $-\mathrm{e}$ & $-\mathrm{ar}$ \\
$1 \mathrm{PL}$ & $-\mathrm{em}$ & $-\mathrm{om}$ \\
$2 \mathrm{PL}$ & $-\mathrm{ep}$ & $-\mathrm{ep}$ \\
$3 \mathrm{PL}$ & $-\mathrm{e}$ & $-\mathrm{a}$
\end{tabular}

The Papuan language Dani (Trans-New Guinea phylum) illustrated in (17) shows a syncretic $2 \mathrm{PL} / 3$ ending -ep in the hypothetical mood which matches the distinct $2 \mathrm{PL}$ ending -ip of the past. (The hypothetical mood is also characterised by a lowering of the vowel of the ending.) In Carib (Kalihna), shown in (18), the interrogative form of the copula distinguishes $2 \mathrm{PL}$ and 3PL, while elsewhere they are syncretic, displaying the form of the 2PL.

Dani (Bromley 1981: 192)

\begin{tabular}{|c|c|c|}
\hline & past & hypothetical \\
\hline $1 \mathrm{SG}$ & $-\mathrm{i}$ & $-e$ \\
\hline $2 \mathrm{SG}$ & -in & -en \\
\hline $3 \mathrm{SG}$ & $-\mathrm{e}$ & -ep \\
\hline 1PL & $-\mathrm{u}$ & -0 \\
\hline $2 \mathrm{PL}$ & -ip $\rightarrow$ & $-e p$ \\
\hline $3 \mathrm{PL}$ & $-\mathrm{a}$ & -ep \\
\hline
\end{tabular}

(18) Carib copula (Hoff 1968: 212)

\begin{tabular}{lll}
\hline & interrogative & present \\
\hline 1SG & way & wa \\
2SG & may & ma:na \\
3SG & nay & may, na \\
1PL & kïta:ton & kïta:ton \\
2PL & mandon $\rightarrow$ & mandoy \\
3PL & nandoy & mandoy
\end{tabular}

\footnotetext{
9 The alternation between syllabic indicative prefixes and asyllabic subjunctive prefixes is phonologically regular: indicative prefixes attach to the (consonant-initial) verb stem, while the subjunctive prefixes precede the subjunctive marker $a$-, which is prefixed to the verb stem.
} 
The Papuan language Suena (Trans-New Guinea phylum) presents a particularly striking example (19): the syncretic 2DU/3DU and 2PL/3PL of the remote tense have the same element $-w$ - that is found in the 2DU and 2PL endings found in the other tenses. (The forms in the first column are used with the future, present, today's past, yesterday's past and past tenses. The vowel symbol $-V$ - denotes the variable mood marker.)

(19) Suena (Wilson 1974: 59)

\begin{tabular}{|c|c|c|}
\hline & default & remote \\
\hline $1 \mathrm{SG}$ & $-n-V$ & $-n-V$ \\
\hline $2 \mathrm{SG}$ & $-\mathrm{s}-\mathrm{V}$ & $-s-V$ \\
\hline $3 \mathrm{SG}$ & $-i-V$ & $-n u-V$ \\
\hline 1INCL DU & $-n-V-g e$ & $-n-V-g e$ \\
\hline 1EXCL DU & $-n-V-$ to & -n-V-to \\
\hline $2 \mathrm{DU}$ & $-\mathrm{w}-\mathrm{V}-$ to $\rightarrow$ & $-\mathrm{w}-\mathrm{V}$-to \\
\hline 3DU & -r-V-to & -w-V-to \\
\hline 1INCL PL & -n-V-kai & -n-V-kai \\
\hline 1EXCL PL & -n-V-kare & -n-V-kare \\
\hline $2 \mathrm{PL}$ & $-\mathrm{w}-\mathrm{V} \longrightarrow$ & $-\mathrm{w}-\mathrm{V}$ \\
\hline 3PL & $-r-V$ & $-\mathrm{w}-\mathrm{V}$ \\
\hline
\end{tabular}

\subsection{First person / second person.}

In the light of the failure of $1 / 3$ and $2 / 3$ syncretism to reflect any consistent morphological hierarchy between these values, we should not be surprised to find the evidence of $1 / 2$ syncretism to be equally inconclusive. In some examples the second person form prevails. Thus, in the non-Pama Nyungan Australian language Burarra (20), 1/2 augmented (plural) and unit-augmented (dual) are marked by the same prefix nyi- which serves for second person in the singular.

(20) Burarra (Glasgow 1984, cited in Cysouw 2003)

\begin{tabular}{|c|c|c|c|}
\hline & minimal & augmented & unit augmented \\
\hline $1 \mathrm{INCL}$ & arr- & ngu-burr- & a-rri- \\
\hline 1 (EXCL) & ngu- & nyi-burr- & nyi-rri- \\
\hline 2 & nyi- $\rightarrow$ & nyi-burr- & nyi-rri- \\
\hline 3 & $(a-)$ & a-burr- & (a)birri- \\
\hline
\end{tabular}


In the Tungusic language Udihe (21), first and second person are syncretic both in the singular and plural in various paradigms, and the form corresponds to the distinct second person form as found in other paradigms. ${ }^{10}$

Udihe (Nikolaeva and Tolskaya 2001: 212-13)

\begin{tabular}{|c|c|c|c|c|c|}
\hline & $\begin{array}{l}\text { past, past } \\
\text { participle }\end{array}$ & present & $\begin{array}{l}\text { permissive, } \\
\text { subjunctive }\end{array}$ & $\begin{array}{l}\text { perfect, } \\
\text { conditional }\end{array}$ & $\begin{array}{l}\text { future, converbs, } \\
\text { present \& future } \\
\text { participles }\end{array}$ \\
\hline $1 \mathrm{SG}$ & $-\mathrm{mi}$ & $-\mathrm{mi}$ & $-\mathrm{mi}$ & $-\mathrm{i}$ & $-\mathrm{i}$ \\
\hline $2 \mathrm{SG}$ & $-\mathrm{i}$ & $-\mathrm{i}$ & $-\mathrm{i}$ & $-\mathrm{i}$ & $-\mathrm{i}$ \\
\hline $3 \mathrm{SG}$ & - ni & -ini, -ili & $\varnothing$ & $\varnothing$ & $-n i$ \\
\hline 1INC PL & $-f i$ & $-\mathrm{fi}$ & $-f i$ & $-\mathrm{ti}$ & $-f i$ \\
\hline 1PL & $-m u$ & $-\mathrm{u}$ & $-\mathrm{u}$ & $-\mathrm{u}$ & $-\mathrm{u}$ \\
\hline $2 \mathrm{PL}$ & $-\mathrm{u} \longrightarrow$ & $-\mathrm{u}$ & $-\mathrm{u}$ & $-\mathrm{u}$ & $-\mathrm{u}$ \\
\hline 3PL & $-\mathrm{ti}$ & -iti, -du- & $-d u-$ & $-\mathrm{du}-$ & $-\mathrm{ti}$ \\
\hline
\end{tabular}

In the Omotic language Shinassha (22), the 1PL subjunctive appears to be based on the 2PL form, in both the prefix conjugation and the suffix conjugation.

(22) Shinassha (Lamberti 2001: 149-53, 163-5)

\begin{tabular}{|c|c|c|}
\hline & \multicolumn{2}{|c|}{ (prefix $\sim$ suffix conjugation) } \\
\hline & default & subjunctive \\
\hline $1 \mathrm{SG}$ & tì- -è & ni- $\sim-$ ee \\
\hline $2 \mathrm{SG}$ & ní- -í & ni- $\sim$-ii \\
\hline 3SG MASC & bí- -é & ni- $\sim$-ee \\
\hline 3SG FEM & bì- -à & bi- $\sim$-aane \\
\hline $1 \mathrm{PL}$ & nò- -ò & it- $\sim$-ate \\
\hline 2PL & $\begin{array}{l}\text { ít- - } \longrightarrow \\
\text { ә } \mathrm{t}\end{array}$ & it- -ate \\
\hline 3PL & bó- -nóó & bo- $\sim-$ noo \\
\hline
\end{tabular}

On the other hand, there are languages where first person form seems to prevail over second. Thus, Nobiin shows this pattern in the plural interrogative (23); note that second person is involved in a different directional effect in the singular (see above, 13). In literary Kannada (24), 1SG is distinguished from 2 sG by the addition of the element $-n u$ in the future. In the past, the $-n u$ element is extended to $2 \mathrm{SG}$.

\footnotetext{
${ }^{10}$ Historically, the second person forms had the form $-s V$, with the $-s$ - lenited to $-h$ - in some varieties of Udihe (Sunik 1997: 238) and to $\varnothing$ in others (including the variety illustrated here).
} 


\begin{tabular}{lll}
\hline & \multicolumn{2}{c}{$($ present $\sim$ past $)$} \\
& indicative & interrogative \\
\hline 1SG & -ir $\sim$-is & -re \\
2SG & -nam $\sim$-onam & $-\mathrm{i} \sim-\mathrm{o}$ \\
3SG & $-\mathrm{i} \sim$-o & $-\mathrm{i} \sim-\mathrm{o}$ \\
1PL & - ir $\sim$-is $\longrightarrow$ & -ro $\sim$-so \\
2PL & -rokom $\sim$-sokom & -ro $\sim$-so \\
3PL & -inna $\sim$-sa & -inna $\sim$-sa
\end{tabular}

\begin{tabular}{|c|c|c|}
\hline & future & past \\
\hline $1 \mathrm{SG}$ & -enu $\rightarrow$ & -enu \\
\hline $2 \mathrm{SG}$ & $-e$ & -enu \\
\hline 3SG M & -anu & -anu \\
\hline $3 \mathrm{SG} F$ & $-a ¥ u$ & $-a ¥ u$ \\
\hline $3 \mathrm{SG} \mathrm{N}$ & -uu & -itu \\
\hline
\end{tabular}

\subsection{First / second / third person}

In the future tense in Gujarati (25), 2SG has no distinct form: it is either identical to the 1SG or to the third person, the two forms being in free variation (Cardona 1964: 142). Note that Dutch displays a similar alternation, at least superficially (see above, 14 ); we do not treat this example as parallel to Gujarati because the $1 \mathrm{SG} / 2 \mathrm{Sg}$ pattern is transparently a default form.

\begin{tabular}{|c|c|c|c|}
\hline \multicolumn{3}{|c|}{ option 1} & option \\
\hline $1 \mathrm{SG}$ & $-\mathrm{i} \check{\mathrm{S}}$ & $\leftarrow$ & $-i \check{s}$ \\
\hline $2 \mathrm{SG}$ & $-\mathrm{išs}$ & & -še \\
\hline 3 & -še & $\rightarrow$ & -še \\
\hline 1PL & $-\breve{s}(\dot{i}$ & & $-\breve{s}(\mathrm{i}) \tilde{u}$ \\
\hline
\end{tabular}

\subsection{Assessment of (1998) and Carstairs-McCarthy's (1998) predictions}

The relationship of the examples from $\S 3.4$ to the markedness hierarchy $2>1>3$ is given in (26). The table is to be read as follows. ' $U$ ' indicates unmarked and ' $M$ ' indicates marked. The symbol to the left of the slash ("/) stands for the syncretized value, the symbol to the right of the slash represents the context. Thus U/U means 'the form associated with the unmarked person value is extended to a marked value in the unmarked context', M/M indicates that the form associated with a marked person value is extended to the unmarked value in a marked context', and so on. We have assumed that values such as singular, present tense, indicative and declarative constitute the unmarked values of contextual features; in a number of cases it is not obvious what markedness values to assume. 


\begin{tabular}{|l|c|c|c|}
\cline { 2 - 4 } \multicolumn{1}{l|}{} & $1 / 2$ & $2 / 3$ & $1 / 3$ \\
\hline a. Koiari & & & $\mathrm{U} / ?$ \\
\hline b. Literary Kannada & $\mathrm{U} / ?$ & & \\
\hline c. Gujarati & $\mathrm{U} / ?$ & $\mathrm{U} / ?$ & \\
\hline d. Nobiin & $\mathrm{U} / \mathrm{M}$ & $\mathrm{U} / \mathrm{M}$ & \\
\hline e. Dutch & & $\mathrm{U} / \mathrm{M}$ & \\
\hline f. Murle & & & $\mathrm{M} / \mathrm{M}$ \\
\hline g. Dani & & $\mathrm{M} / \mathrm{M}$ & \\
\hline h. Suena & & $\mathrm{M} / \mathrm{M}$ & \\
\hline i. Burarra & $\mathrm{M} / \mathrm{M}$ & $\mathrm{M} / \mathrm{M}$ & \\
\hline j. Shinasha & $\mathrm{M} / ?$ & & \\
\hline k. Udihe & & $\mathrm{M} / ?$ & \\
\hline l. Callahuaya & & $\mathrm{M} / \mathrm{U}$ & \\
\hline m. Kongo & & $\mathrm{M} / \mathrm{U}$ & \\
\hline n. Old Icelandic & & $\mathrm{M} / \mathrm{U}$ & \\
\hline o. Carib & & & \\
\hline
\end{tabular}

The results shown in (26) do not strongly favour either Noyer's (1998) impoverishment model or Carstair's-McCarthy's lexical semantic model. (26a-c) are compatible with both models, because the unmarked form prevails in what could be construed as the unmarked context. (26d-e) are compatible with impoverishment but not with the lexical semantic model, because the unmarked form is extended in the marked context. On the other hand, (26f-o) are not compatible with impoverishment, because they involve extension of the marked form. Of these, (26f-l) are compatible with the lexical semantic model, because the marked form is extended in the marked form, while (26m-o) appear to be incompatible with both models, because they involve the extension of the marked form in the unmarked context. Even those examples which would appear to comply with one or the other of the predictions may pose problems when subjected to a more detailed morphological analysis (as pointed out by a referee). Thus, the facts adduced in $\$ 3.4$ suggest, at the very least, that the theoretical predictions should be reconsidered. ${ }^{11}$

\subsection{A note on diachrony}

Directionality can also be observed in diachrony, where one form replaces another over time. A familiar example, adduced in Kuryłowicz's famous article on analogy (1949), involves Old Icelandic, cited above in (16). These paradigms are interpreted as the result of the extension of the $2 \mathrm{SG}$ ending to the $3 \mathrm{SG}$ in place of the expected $*_{-} p$ (Haugen 1982: 129). The syncretic pattern itself is attributed to analogy with

\footnotetext{
${ }^{11}$ Further permutations of Noyer's and Carstairs-McCarthy's predictions are possible, but they do not improve matters greatly. In the case of Noyer's model, one can also allow for simple underspecification, without the device of impoverishment (as described in (7)). For example, the plural

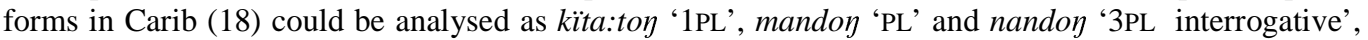
with 2PL/3PL syncretism due to the underspecification of mandoy. In this is allowed, Noyer's model makes no obvious predictions about directionality. On the other hand, Carstairs-McCarthy's model may be more restrictive than has been assumed here, since he assumes that feature structure is flat. Thus, there can be no markedness relation between marked values. The consequence of this would seem to be the prediction that directional effects should not obtain between marked values, which is contradicted by all the examples of $1 / 2$ person syncretism.
} 
consonant-stem verbs, where it was the result of a general phonological development (syncope of the theme vowel and assimilation of the ending into the stem-final consonant; Kuryłowicz 1949). As with synchronic directionality, various patterns are found.

Many examples involve extension of the third person form, which would follow from the assumption that third person serves as a default. For example, in Livonian (27), the 3SG present tense ending $-b$ is found in place of the expected 1SG ending $*_{-} n \rightarrow-\varnothing$ (Viitso 1997: 112). Compare the paradigm from the closely related Estonian, where the original $1 \mathrm{SG}$ ending is found. ${ }^{12}$ Note that in monosyllabic stems in West Livonian dialects, vacillation was recorded between the original $1 \mathrm{sG}$ form and the innovative one, thus the verb 'to be' has the singular forms uo or uob '1sG', uod '2SG', uob '3SG' (Kettunen 1938: 1x). Kettunen (1938: lx-lxii) attributes this to analogy with the preterite paradigm, where 1SG and 3SG fell together as the result of regular sound change. Thus, as with Old Icelandic, the syncretic pattern was already established in the language by regular sound change. (Note that the 2PL/3PL pattern of the preterite was not extended.)

\begin{tabular}{|c|c|c|c|c|}
\hline & \multicolumn{2}{|c|}{ present } & \multicolumn{2}{|c|}{ preterite } \\
\hline & Livonian & Estonian & Livonian & Estonian \\
\hline $1 \mathrm{SG}$ & lugub & loen & lugiz & lugesin \\
\hline $2 \mathrm{SG}$ & lugud & loed & lugist & lugesid \\
\hline $3 \mathrm{SG}$ & lugub & loeb & lugiz & luges \\
\hline $1 \mathrm{PL}$ & lu'ggəm & loeme & lugizmə & lugesime \\
\hline $2 \mathrm{PL}$ & lu'ggət & loete & lugist(ə) & lugesite \\
\hline $3 \mathrm{PL}$ & lu'ggəbəd & loevad & lugist(ə) & lugesid \\
\hline
\end{tabular}

German likewise shows what appears to be the extension of third person forms. In Middle High German (MHG), all persons were distinct in the present tense plural; by the Early New High German (ENHG) period, four different syncretic patterns were found, varying according to dialect (28). In type I, the third person form has been extended to second person. In type II, it has been extended to all three persons. In type III (ultimately established as the literary norm), 1PL and 3PL are syncretic. Though the form looks like the original 1PL, the source is more likely to have been the $-n$ found in the 3PL preterite, likewise $-n$. In IV, this $-n$ is extended to all plural persons.

\footnotetext{
${ }^{12}$ Though note that the expected reflex of final $-n$ should be $-\varnothing$ in Estonian as well. Its retention in 1 SG forms is anomalous.
} 
(28) Present tense endings in Early New High German (Wegera 2000: 1546, Grosse 2000: 1333)

\begin{tabular}{|c|c|c|c|c|c|}
\hline & MHG & I & II & III & IV \\
\hline $1 \mathrm{PL}$ & $-n$ & $-n$ & $-n t$ & $-n$ & $-n$ \\
\hline $2 \mathrm{PL}$ & $-t$ & $-n t$ & $-n t$ & $-t$ & $-n$ \\
\hline $3 \mathrm{PL}$ & $-n t$ & $-n t$ & $-n t$ & $-n$ & $-n$ \\
\hline
\end{tabular}

The third person also prevails in the Kumta dialect of Kannada (29), where, in place of the historically expected 1PL ending $-v V$ (found in other dialects, as well as the literary language), the 3PL ending $-r u$ is found. As in the German examples above (28), this same ending may replace the 2PL ending -ri as well.

(29) Kannada dialects 'kept' (Upadhyaya 1976: 130-2)

\begin{tabular}{lll}
\hline & Bellary & Kumta \\
\hline 1PL & $\mathrm{i} \cdot$ ive & $\mathrm{i} \cdot$ ru \\
2PL & $\mathrm{i} \cdot$ ri & $\mathrm{i} \cdot$ ru /- \\
& & $\mathrm{ri}$ \\
3PL & $\mathrm{i} \cdot$ ru (masc., fem.) & $\mathrm{i} \cdot$ ru \\
& $\mathrm{i} \cdot$ uvu (neut.) &
\end{tabular}

A similar development has been reconstructed for the plural passive of Gothic: 1PL and 3PL fell together by regular sound change, and the 2PL was analogically altered to match them, leading to the attested 1PL/2PL/3PL ending -anda (Szemerenyi 1989: 255).

A particularly striking example of the extension of third person forms comes from the Oceanic language Anejom (30). In the nineteenth century, the auxiliary had distinct forms for first person (inclusive and exclusive), second and third in the dual, trial and plural. Between the nineteenth and twentieth century the language underwent catastrophic change (due in part to population loss). The result is a system with considerable variation, if not to say confusion. Lynch (2000) hypothesizes that it is moving in the direction of generalizing the third person plural for all non-singular persons. 


\begin{tabular}{|c|c|c|}
\hline & \multicolumn{2}{|c|}{ aorist (typical for all paradigms) } \\
\hline & 19th c. & 20th c. \\
\hline $1 \mathrm{SG}$ & ek & ek \\
\hline $2 \mathrm{SG}$ & na & na \\
\hline $3 \mathrm{SG}$ & et & et \\
\hline 1INCL DU & intau & \\
\hline 1DU & ecrau & \\
\hline $2 \mathrm{DU}$ & ekau & \\
\hline 3DU & erau & \\
\hline 1INCL TRI & intaj & \\
\hline 1TRI & ektaj, ektij & era \\
\hline $2 \mathrm{TRI}$ & ahtaj & \\
\hline 3TRI & ehtaj & \\
\hline 1INCL PL & inta & \\
\hline 1PL & ecra & \\
\hline 2PL & eka & \\
\hline 3PL & era & \\
\hline
\end{tabular}

However, not all such examples favour the third person. Thus, Romani shows evidence of multiple directionality. (31). In the present tense, syncretism of 2PL/3PL is common to all the dialects. (The origin of this pattern is unclear, so we take it as a given.) ${ }^{13}$ What is of interest to us is the extension of this pattern into the perfect, which occurs in a few dialects. Significantly, it is sometimes the 2PL ending which prevails (Sinti), and sometimes the 3PL ending (Northeastern Romani, and partly in Welsh Romani).

(31) Romani (Matras 2002: 145)

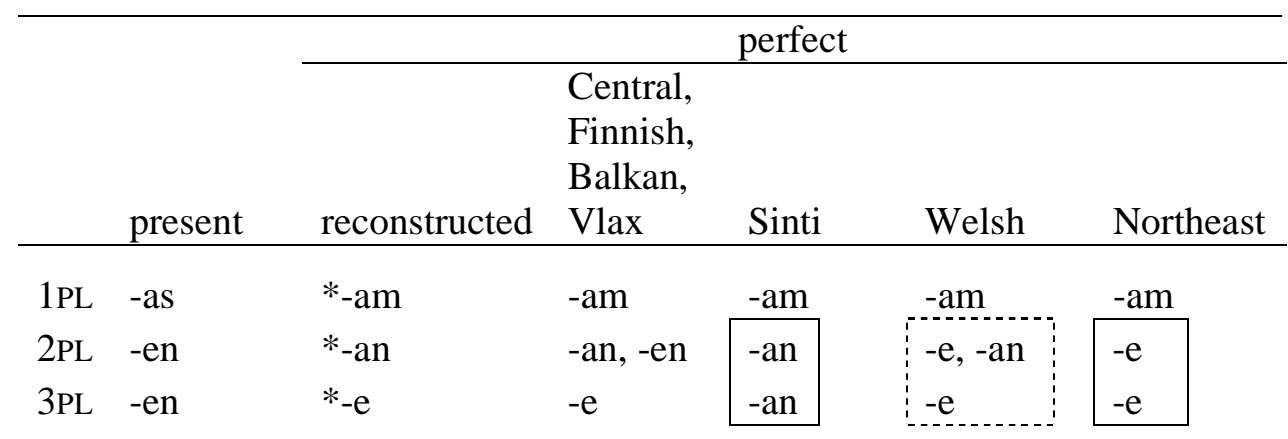

Thus, while there is some diachronic evidence that third person forms can replace others diachronically, it is hardly an exceptionless generalization. Especially striking are the examples that appear to show second person replacing third, for which no explanation readily comes. Nevertheless, there is one area where the default status of third person is more firmly established, namely the wholesale loss of person

\footnotetext{
${ }^{13}$ The syncretic 2PL/3PL corresponds to what would be expected for the 3PL (Matras 2002: 143). This is unexplained, but it may be connected with the resemblance between the 2PL perfect ending -an and the 3PL present ending -en.
} 
marking, as seen above in German, the Kumta dialect of Kannada and in Gothic; in all these examples it is the etymological third person form which prevails. A seeming counterexample to this observation comes from the present tense in Modern East Scandinavian languages (Swedish, Danish and Norwegian), where person distinctions have been eliminated, and there is but a single form in $-r$ (see 16 above). The first stage in this development was shared with Old Icelandic, namely the extension of second person $-r$ to the third person in the present indicative. However, it was only after it was extended to third person singular that this form ultimately predominated (32); that is, the form which was extended to all person values served as a third person form (among other things) immediately prior to its extension.

\section{Eastern Scandinavian (present indicative)}

\begin{tabular}{|c|c|c|c|}
\hline & proto-ES & Old ES & Modern ES \\
\hline $1 \mathrm{SG}$ & $*_{-}(\mathrm{V})$ & $-(\mathrm{V})$ & $-(\mathrm{V}) \mathrm{r}$ \\
\hline $\begin{array}{l}2 \mathrm{SG} \\
3 \mathrm{SG}\end{array}$ & $\begin{array}{l}*_{-}(\mathrm{V}) \mathrm{r} \rightarrow \\
*_{-}(\mathrm{V}) \mathrm{b}\end{array}$ & $\begin{array}{l}-(V) r \\
-(V) r\end{array}$ & $\begin{array}{l}-(\mathrm{V}) \mathrm{r} \\
-(\mathrm{V}) \mathrm{r}\end{array}$ \\
\hline
\end{tabular}

This suggests that two types of operation were at work: (i) an idiosyncratic, morphologically specified extension of the second person to the third, and (ii) a crosslinguistically unexceptional extension of the $3 \mathrm{SG}$ form.

In some of these cases, for example in Old (and Modern) Icelandic, the diachronic extension of a form has resulted in synchronic directionality, provided the extension did not affect all paradigms. However, there is another potential source for synchronic directional effects. Consider Nobiin (see 13 above), where the 3sG form appears to be the source for the syncretic $2 \mathrm{SG} / 3 \mathrm{SG}$ interrogative, and the 1PL form appears to be the source for the 1PL/2PL interrogative. In the the ancestor of Nobiin, Old Nubian (first attested in the seventh century; Browne 2002: 1), 2sG/3SG and 1PL/2PL syncretism was characteristic of all paradigms (33).

\section{Old Nubian present indicative (Bechhaus-Gerst 1996: 237)}

\begin{tabular}{lll}
\hline & SG & PL \\
\hline 1 & -ire & -iro \\
2 & -ina, -ena & -iro \\
3 & -ina, -ena & -iran, -eran
\end{tabular}

In Nobiin, 2SG and 2PL suffixes were innovated and added to the indicative and negative paradigms, but not to the interrogative or conditional. Thus, the syncretic paradigms represent the older state of affairs, and the directional effect that results is a reflection of diachronic layering.

\section{Conclusion}

The contrast is often made between a restrictive theory, which is able to make predictions about possible and impossible structures, and a descriptive framework, which is open-ended. The question we have posed above is: to what extent can a formal model of syncretism serve as a restrictive theory? The results are not 
encouraging. In $\$ 2$ we reviewed a recent model of the internal feature structure of person, and showed that it does not allow us to predict the attested patterns of syncretism. In $\S 3$ we compared two different models which aim, among other things, to derive directional effects in syncretism, and showed that neither makes empirically verifiable predictions. In fact, the data are heterogeneous enough to make any prediction circular; at best, what the model cannot account for can be labelled 'accidental' (see fn. 3). This suggests that a formal model should not presume to make predictions.

However, it would be irresponsible to leave the matter there. There are some decided tendencies, for example, the prevalence of syncretism of $1 / 2$ and $2 / 3$ person in non-singular numbers (suggesting that these do constitute natural classes at some level), and the frequency with which third person serves as a default in diachronic change. The challenge for morphological theory is to allow the formal model to be open-ended, while still giving an account of the fact that some patterns are common, and others rare. Below we suggest that the statistical distribution of patterns is a reflection of diachronic processes.

Consider first the change undergone by Anejom, discussed above in (30). Though striking in its rapidity, the direction of change does not seem unexpected: third person substitutes for the other forms, and plural substitutes for dual and trial. The basis for the innovative system of twentieth century Anejom need not be sought in language-specific morphological quirks. Rather, it follows from quite widespread assumptions about the unmarkedness of the third person with respect to other person values, and of plural with respect to other non-singular number values.

Contrast this with the developments in the Cushitic language Dhaasanac, illustrated in (34). In the tense-aspect paradigms where person is marked (the perfect and imperfect positive, the dependent positive and the short past) there are two distinct stems, which Tosco (2001) labels 'A' and 'B' (following Sasse 1976). The contrast between the A and B forms is illustrated in (34). It takes a number of different shapes, depending on the verb stem, involving stem-final (a-e) or stem-initial (f) consonant alternations and vowel insertion (c) and alternation (d-e). The distribution of the A and B forms can hardly be described as reflecting any natural classes of morphosyntactic values: the A form is used for the first person singular, third person singular masculine, first person inclusive plural and the third person plural, while form B is used for the second person in both numbers, third person singular feminine and the first person exclusive plural. What is of interest here is that this morphologically systematic, morphosyntactically unnatural pattern is itself the product of a morphological innovation. The stem alternations descend from an older system of affixation: most verbs took person-number marking suffixes, a small handful took prefixes. This state of affairs is still found in other Cushitic languages, such as Somali. Crucially, the first person exclusive form in $-n$ was distinct from the 2/3SG FEM form in - $t$. Under Sasse's (1976: 219-20) reconstruction (35), forms in - $n$ and $-t$ fell together by regular sound change in stems ending in a resonant. This syncretism was then extended by analogy to all other stem classes, as well as to stems with person-number prefixes. 


\begin{tabular}{lll}
\hline \multicolumn{3}{c}{ examples of stem alternation } \\
A & B & \\
\hline a. lee $\Delta \mathrm{i}$ & leeti & 'fall down.PERF' \\
b. kufi & kuyyi & 'die. PERF' \\
c. guurma & guuranna & 'migrate. IMPERF \\
d. ?uufumi & ?uufeeni & 'cough. PERF' \\
e. se $\Delta$ & sieti & 'walk. PERF' \\
f. yes & ces & 'kill. PERF'
\end{tabular}

\begin{tabular}{llc}
\hline & $\begin{array}{c}\text { attested } \\
\text { state }\end{array}$ & $\begin{array}{c}\text { original } \\
\text { state }\end{array}$ \\
\hline 1SG & A & $* \varnothing$ \\
2SG & B & $\begin{array}{r}*-t \\
*-t\end{array}$ \\
3SG FEM & B & $* \varnothing$ \\
3SG MASC & A & $* \varnothing$ \\
1INCL PL & A & $*$-n \\
1EXCL PL & B \\
2PL & B & $*$-t \\
3PL & A & $* \varnothing$
\end{tabular}

Thus, the change in Anejom yielded a 'natural' result, while the change in Dhaasanac yielded an unnatural result. But in essence the two kinds of change are the same. The original paradigmatic space was reorganized according to a new template. The difference lies in the source of the template. In the case of Anejom, we can suppose its source lay in (universal?) properties of feature structure, whereby 3PL is unmarked with respect to other non-singular person-number values. Thus, this template is shared across most (all?) languages. In the case of Dhaasanac, the template was created by a phonological change that affected one stem class. By definition, this template is language-specific. The difference between natural (i.e. common) and unnatural (i.e. uncommon) syncretic patterns thus need not be reflected in the formal model. We suggest that contrast between these two diachronic routes is sufficient to account for the statistical predominance of morphosyntactically natural patterns, as argued also by Cysouw (forthcoming b). Paradigmatic templates based on common or universal elements of feature structure (i) are available to all languages, (ii) can arise spontaneously (as in Anejom), and (iii) are self-regenerating in case of disruptions. Templates based on phonological change, although they may be resistant to change, and even productive (Maiden 1992), nevertheless are still languagespecific, and always in competition with templates based on feature structure. It only follows that the former type should be more widespread.

On this view, even if we manage to construct a comprehensive model of feature structure that will account for some syncretic patterns, the possibility still remains that patterns may be codified which are independent of feature structure. The crucial question here is whether there are any constraints on the production of unnatural syncretic patterns. At present we do not have enough information to decide 
this question; as the discussion above will have shown, it can only be resolved empirically. 


\section{Appendix 1: Person syncretism in 109 languages}

The core of the sample is based on the 200 language corpus used in Dryer et al. (forthcoming), which has been expanded. Complete syncretism (where the syncretic pattern is systematically found in all the paradigms of a language) is marked by ' $x$ ', partial syncretism (restricted in scope, e.g. by tense-aspect-mood, lexical class, gender or syntactic context) is marked by '( $\mathrm{x})$ '. Syncretism of number that affects only one person value is not recorded here. For example, in Latvian, 2SG may be syncretic with third person, which does not distinguish number; this is recorded as $2 / 3$ syncretism in the singular.

\begin{tabular}{|l|l|l|l|l|l|l|l|l|l|l|}
\hline \multirow{2}{*}{ Language } & \multicolumn{3}{|c|}{ singular } & \multicolumn{3}{c|}{ non-singular } & \multicolumn{2}{l}{ number } \\
irrelevant
\end{tabular}




\section{Appendix 1, continued}

\begin{tabular}{|c|c|c|c|c|c|c|c|c|c|c|}
\hline \multirow[t]{2}{*}{ Language } & \multicolumn{3}{|c|}{ singular } & \multicolumn{3}{|c|}{ non-singular } & \multicolumn{3}{|c|}{$\begin{array}{l}\text { number } \\
\text { irrelevant }\end{array}$} & \multirow[b]{2}{*}{ other patterns } \\
\hline & $1 / 3$ & $2 / 3$ & $1 / 2$ & $1 / 3$ & $2 / 3$ & $1 / 2$ & $1 / 3$ & $2 / 3$ & $1 / 2$ & \\
\hline Gimira & & & & & $(\mathrm{x})$ & & & & & $\begin{array}{l}\text { (3SG/2PL/3PL/ } \\
1 \mathrm{INCL} P L)\end{array}$ \\
\hline Guambiano & & & & & & & & $\mathrm{x}$ & & \\
\hline Harar Oromo & $(\mathrm{x})$ & $(\mathrm{x})$ & & & & & & & & \\
\hline Hayu & & $\mathrm{x}$ & & & $\mathrm{x}$ & & & & & $\begin{array}{l}(2 \mathrm{DU} / 3 \mathrm{DU} / 1 \mathrm{INCL} \\
\mathrm{DU})\end{array}$ \\
\hline Hindi & & $\mathrm{x}$ & & $\mathrm{x}$ & & & & & & \\
\hline Hixkaryana & & & & $\mathrm{x}$ & & & & & & \\
\hline Hunzib & & & & & & & & & $\mathrm{X}$ & \\
\hline Ibibio & & & & & & & & $(\mathrm{x})$ & & (3SG/PL) \\
\hline Ika & $(\mathrm{x})$ & & & & & $(\mathrm{x})$ & & & & \\
\hline Ingush & & & & & & & & & $\mathrm{X}$ & \\
\hline Iraqw & & $(\mathrm{x})$ & & & & & & & $(\mathrm{x})$ & \\
\hline Irish & & & & & & & & & & $\begin{array}{l}(3 \mathrm{SG} / 2 \mathrm{PL}),(2 / 3), \\
(\mathrm{SG} / 2 \mathrm{PL} / 3 \mathrm{PL})\end{array}$ \\
\hline Kannada & & & $(\mathrm{x})$ & & & & & & & \\
\hline Kapau & & & & & $\mathrm{x}$ & & & & & (1SG/2PL/3PL) \\
\hline Karok & & & & & & & & $(\mathrm{x})$ & & \\
\hline Kashmiri & & & & $(\mathrm{x})$ & & & $(\mathrm{x})$ & & & \\
\hline Ket & & & & & & & $(\mathrm{x})$ & & & \\
\hline Kewa & & & $(\mathrm{x})$ & & $\mathrm{x}$ & & & & & \\
\hline Khanty & & & & & $(\mathrm{x})$ & & & & & \\
\hline Kiowa & & & & $(\mathrm{x})$ & & & & & & (3SG/1PL) \\
\hline Kiwai & & & & & & & & $\mathrm{x}$ & & \\
\hline Kobon & & $(\mathrm{x})$ & & & $\mathrm{x}$ & & & & & \\
\hline Koiari & $\mathrm{x}$ & & & & & & & & & \\
\hline Kongo & & $(\mathrm{x})$ & & & & & & & & \\
\hline Koryak & & $(\mathrm{x})$ & & & & & & & & \\
\hline Krongo & & & $(\mathrm{x})$ & & & & & & & \\
\hline Kunama & & & $(\mathrm{x})$ & & $(\mathrm{x})$ & & & & & \\
\hline Kwamera & & & & $(\mathrm{x})$ & & & & & & \\
\hline Lak & & & & & & & & $(\mathrm{x})$ & $(\mathrm{x})$ & \\
\hline Lango & & & & & & & & & & 3PL/1DU \\
\hline Latvian & & $(\mathrm{x})$ & & & & & & & & \\
\hline Lavukaleve & & & & & & $(\mathrm{x})$ & & & & \\
\hline $\begin{array}{l}\text { Lower Grand } \\
\text { Valley Dani }\end{array}$ & & & & & $(\mathrm{x})$ & & & & & \\
\hline Luvale & & $(\mathrm{x})$ & & $(\mathrm{x})$ & & & & & & \\
\hline Manchad & & & & & & $(\mathrm{x})$ & & & & \\
\hline Marind & & & & & & & & & & (3SG/2PL) \\
\hline Me'en & & $(\mathrm{x})$ & & & & & & & & \\
\hline Miskito & & & & & & & & & $\mathrm{X}$ & \\
\hline Muna & & & & & & & & & & $\begin{array}{l}\text { (3PL/1inc DU), } \\
\text { (2SG/1PL) }\end{array}$ \\
\hline
\end{tabular}




\section{Appendix 1, continued}

\begin{tabular}{|c|c|c|c|c|c|c|c|c|c|c|}
\hline \multirow[t]{2}{*}{ Language } & \multicolumn{3}{|c|}{ singular } & \multicolumn{3}{|c|}{ non-singular } & \multicolumn{3}{|c|}{$\begin{array}{l}\text { number } \\
\text { irrelevant }\end{array}$} & \multirow[b]{2}{*}{ other patterns } \\
\hline & $1 / 3$ & $2 / 3$ & $1 / 2$ & $1 / 3$ & $2 / 3$ & $1 / 2$ & $1 / 3$ & $2 / 3$ & $1 / 2$ & \\
\hline Murle & $(\mathrm{x})$ & $(\mathrm{x})$ & & & & & $(\mathrm{x})$ & & & \\
\hline Nama & & (x) & & & & & & & & \\
\hline Nez Perce & & & & & & & & & $\mathrm{x}$ & \\
\hline Nganasan & & & & & & & & $(\mathrm{x})$ & & \\
\hline Ngiti & & & & $(\mathrm{x})$ & & & & & & \\
\hline Nivkh & & $\mathrm{x}$ & & & & & & & & \\
\hline Nkore-Kiga & & & & $(\mathrm{x})$ & & & & & & \\
\hline $\begin{array}{l}\text { Nubian } \\
\text { (Dongala) }\end{array}$ & & $\mathrm{x}$ & & & & $\mathrm{x}$ & & & & (SG/1PL/2PL) \\
\hline Nunggubuyu & & & & & & $(\mathrm{x})$ & & & & \\
\hline Olo & & & & & & & & & & (1PL/3DU) \\
\hline Otomi & & & & & & & & $(\mathrm{x})$ & & \\
\hline Pumi & & & & & & $\mathrm{X}$ & & & & (2SG/3/1PL/2PL) \\
\hline Rongpo & & $(\mathrm{x})$ & & & & $(\mathrm{x})$ & & & & \\
\hline Sango & & & & & & & & & $\mathrm{X}$ & \\
\hline Sentani & & & & & & & & & & (2SG/3DU) \\
\hline Shuswap & & & & & & & & & & 3SG/1PL \\
\hline Siuslaw & & & & & & & & & & 2SG/3PL \\
\hline Slovene & & & & & $\mathrm{x}$ & & & & & \\
\hline Spanish & & & $(\mathrm{x})$ & & & & & & & \\
\hline Suena & & & & & $(\mathrm{x})$ & & & & & \\
\hline Swahili & & $(\mathrm{x})$ & & & & & & & & \\
\hline Tanglapui & & & & & & & & $(\mathrm{x})$ & & \\
\hline Taos & & $(\mathrm{x})$ & & & & $(\mathrm{x})$ & & & & \\
\hline \multicolumn{11}{|l|}{ Telugu } \\
\hline Tetun & & & & & & & & & $\mathrm{x}$ & \\
\hline Tiwi & & $(\mathrm{x})$ & & & & $(\mathrm{x})$ & & & & \\
\hline Tlapanec & & & & & & & & & & (1SG/3PL) \\
\hline Tol & & $(\mathrm{x})$ & $(\mathrm{x})$ & & & & & & & \\
\hline Totonac & & & & & & & & & & (3SG/1PL) \\
\hline Udihe & & & $(\mathrm{x})$ & & & $(\mathrm{x})$ & & & & \\
\hline Usan & & & & & & & & $(\mathrm{x})$ & & \\
\hline Vanimo & $(\mathrm{x})$ & $(\mathrm{x})$ & & $(\mathrm{x})$ & & & & & & (1SG/2PL) \\
\hline Wambon & & & & & & & & $\mathrm{x}$ & & \\
\hline Warekena & & & & & $\mathrm{x}$ & & & & & \\
\hline Waskia & & & & & & & & & $\mathrm{X}$ & \\
\hline Yele & & & & & & & & & & $\begin{array}{l}\text { (2SG/1DU), } \\
(1 \mathrm{PL} / 2 \mathrm{DU})\end{array}$ \\
\hline Yukaghir & & & $(\mathrm{x})$ & & & & & & & $\begin{array}{l}(1 \mathrm{SG} / 2 \mathrm{SG} / 3 \mathrm{SG} / \\
1 \mathrm{PL} / 2 \mathrm{PL})\end{array}$ \\
\hline Zoque & $\mathrm{x}$ & & & & & & & & & \\
\hline Zulu & & $(\mathrm{x})$ & & & & & & & & (3SG/1PL) \\
\hline
\end{tabular}


Appendix 2: Genetic affiliation of the languages in the sample

In general, the attribution of genetic affiliation follows that assumed in Dryer et al. (forthcoming).

Afro-Asiatic: Arabic, Beja, Gimira, Harar Oromo, Iraqw; Altaic: Udihe; Arawakan: Warekena; Austronesian: Kwamera, Muna, Tetun; Aymaran: Aymara; Burarran: Burarra; Carib: Carib (Kalihna), Hixkaryana: Isolates: Atakapa, Burushaski, Cayuvava, Chitimacha, Ket, Nivkh, Nunggubuyu, Tiwi, Tlapanec, Tol, Yukaghir; Chibchan: Ika, Miskito; Chukoto-Kamchatkan: Koryak, Dravidian: Kannada, Telugu; East Papuan: Lavukaleve, Yele; Eskimo-Aleut: Aleut; Ge-Kaingang: Canela-Kraho; Guaicuruan: Abipon; Hokan: Karok; Indo-European: Bulgarian, Dimili, English, French, German, Hindi, Irish, Kashmiri, Latvian, Slovene, Spanish; Kordofanian: Krongo; Khoisan: Nama; Kiowa-Tanoan: Kiowa, Taos; NakhDagestanian: Dargi, Hunzib, Ingush, Lak, Niger-Congo: Diola-Fogny, Dogon, Ewe, Ibibio, Kongo, Luvale, Nkore-Kiga, Sango, Swahili, Zulu, Nilo-Saharan: Bagirmi, Kunama, Lango, Me'en, Murle, Ngiti, Nubian (Dongala); Oto-Manguean: Chichimec, Otomi; Paezan: Awa Pit, Guambiano; Panoan: Amahuaca; Penutian: Nez Perce, Siuslaw; Salish: Shuswap; Sko: Vanimo; Tibeto-Burman: Hayu, Manchad, Primi, Rongpo; Tucanoan: Barasano; Torricelli: Olo; Totonacan: Totonac; Trans-New Guinea: Amele, Daga, Ekagi, Kapau, Kewa, Kiwai, Kobon, Koiari, Lower Grand Valley Dani, Marind, Salt-Yui, Sentani, Suena, Tanglapui, Usan, Wambon, Waskia; Tucanoan: Barasano; Uralic: Estonian, Khanty, Nenets. 


\section{References}

Bechhaus-Gerst, M. 1996. Sprachwandel durch Sprachkontakt am Beispiel des Nubischen im Niltal. Köln: Köppe.

Bierwisch, M. 1967. Syntactic features in morphology: general problems of so-called pronominal inflection in German. In: To honor Roman Jakobson: essays on the occasion of his seventieth birthday (vol. 1). The Hague: Mouton. 239-270.

Blevins, James P. 1995. Syncretism and paradigmatic opposition. Linguistics and Philosophy 18. 113-152.

Bobaljik, J. 2002. Syncretism without paradigms: Remarks on Williams 1981, 1994. In: G. Booij and J. van Marle (eds) Yearbook of Morphology 2001. Dordrecht: Kluwer. 53-86.

Bromley, H. M. 1981. A grammar of Lower Grand Valley Dani. (Pacific Linguistics C63). Canberra: Australian National University.

Browne, G. M. 2002. A grammar of Old Nubian. Munich: Lincom.

Calabrese, A. 1998. Some remarks on the Latin case system and its development in Romance. In J. Lema and E. Treviño (eds) Theoretical analyses on Romance languages. Amsterdam/Philadelphia: John Benjamins. 71-126.

Cardona, G. 1964. A Gujarati reference grammar. Philadelphia: University of Pennsylvania Press.

Cardona, G. and B.K. Suthar. 2003. Gujarati. In: G. Cardona and D. Jain (eds) The Indo-Aryan languages. London: Routledge.

Carstairs, A. 1987. Allomorphy in inflection. London: Croom Helm.

Carstairs-McCarthy, A. 1998. Comments on the paper by Noyer. In: S.G. Lapointe, D.K. Brentari, and P.M. Farrell (eds), Morphology and its relation to phonology and syntax. Stanford: CSLI Publications. 286-301.

Carter, H. and J. Makoondekwa. 1979. Kongo course: maloòngi makikóongo (dialect of Zoombo, Angola). London: School of Oriental and African Studies, University of London.

Clairis, C. 1985. El Qawasqar: linguistica fueguina, teoria y descripcion. (Estudios filologicos, Anejo 12.) Valdivia, Chile: Faculted de Filosofia y Humanidades, Universidad Austral de Chile.

Corbett, G. G. and N. Fraser. 1993. Network morphology: A DATR account of Russian nominal inflection. Journal of Linguistics 29: 113-42

Cysouw, M 2003. The paradigmatic structure of person marking. Oxford: Oxford University Press

Cysouw, M. Forthcoming a. Syncretisms involving clusivity. In: E. Filimonova (ed.) Clusivity. Amsterdam: Benjamins.

Cysouw, M. Forthcoming b. What it means to be rare: the case of person marking. In: Z. Frajzyngier and D. Rood (eds) Linguistic diversity and language theories. Amsterdam: Benjamins.

Dryer, M., M. Haspelmath, D. Gil and B. Comrie (eds). Forthcoming. World atlas of language structures. Oxford: Oxford University Press.

Dutton, T. 2003. A dictionary of Koiari, Papua New Guinea, with grammar notes. Canberra: The Australian National University.

Foley, W.A. 1991. The Yimas Language of New Guinea. Stanford: Stanford University Press.

Frank, P. 1990. Ika syntax. Dallas: Summer Institute of Linguistics.

Glasgow, K. 1984. Burarra word classes. In: K Glasgow, A. Capell et al. (eds) Papers in Australian linguistics 16 (Pacific Linguistics A68). Canberra: Australian National University. 1-54. 
Grosse, S. 2000. Morphologie des Mittelhochdeutschen. In: W. Besch, O. Reichmann and S. Sonderegger (eds) Sprachgeschichte. Ein Handbuch zur Geschichte der deutschen Sprache und ihrer Erforschung [volume 1.2]. Berlin: Mouton de Gruyter. 1332-1340.

Harley, H. and E. Ritter. 2002. Person and number in pronouns: a feature-geometric analysis. Language 78/3. 482-526.

Haugen, E. 1982. Scandinavian language structures: a comparative historical survey. Minneapolis: University of Minnesota Press.

Hoff, B. J. 1968. The Carib Language: Phonology, Morphology, Texts and Word Index. The Hague: M. Nyhoff.

Jackendoff, R. 1985. Multiple subcategorization and the $\theta$-criterion: the case of climb. Natural Language and Linguistic Theory 3: 271-95.

Jakobson, R. O. 1958/1984. Morphological observations on Slavic declension (the structure of Russian case forms) [translation of Morfologičeskie nabljudenija nad slavjanskim skloneniem (sostav russkix padežnix form), originally in American contributions to the Fourth International Congress of Slavists, Moscow]. In: L. R. Waugh and M. Halle (eds) Roman Jakobson. Russian and Slavic grammar: Studies 1931-1981. Berlin: Mouton de Gruyter. 105-133.

Jakobson, R.O. 1936/1984. Contribution to the general theory of case: general meanings of the Russian cases [translation of Beitrag zur allgemeinen Kasuslehre: Gesamtbedeutung der russischen Kasus, originally in TCLP 4]. In: L. R. Waugh and M. Halle (eds) Roman Jakobson. Russian and Slavic grammar: Studies 19311981. Berlin: Mouton de Gruyter. 59-103.

Kettunen, L. 1938. Livisches Worterbuch; mit grammatischer Einleitung. Helsinki: Suomalais Ugrilainen Seura.

Kuryłowicz, J.. 1949 [1973]. De la nature des procès dits 'analogiques'. Reprinted in: Esquisses linguistiques 1. Munich: Fink. 66-86.

Kutsch Lojenga, C. 1994. Ngiti: A Central-Sudanic language of Zaire. Cologne: Rudiger Koppe Verlag.

Lamberti, M. 1993. Die Shinassha-Sprache. Heidelberg: Universitätsverlag C. Winter.

Lefebvre, C. and A.-M. Brousseau. 2002. A grammar of Fongbe. Berlin: Mouton de Gruyter.

Lindstrom, L. and J. Lynch. 1994. Kwamera. Munich: Lincom.

Lipkind, W. 1945. Winnebago grammar. New York: King's Crown Press.

Lumsden, J. S. 1992. Underspecification in grammatical and natural gender. Linguistic Inquiry 23. 469-486.

Lynch, J. 2000. A grammar of Anejom. Canberra: Australian National University.

Lyth, R. E. 1971. A Murle grammar. Linguistic Monograph Papers No. 7. Khartoum: Sudan Research Unit, Faculty of Arts, University of Khartoum.

Maiden, M. 1992. Irregularity as a determinant of morphological change. Journal of Lingusitics 28/2. 285-312.

Matras, Y. 2002. Romani: a linguistic introduction. Cambridge: Cambridge University Press.

Müller, G. Forthcoming. A Distributed Morphology approach to syncretism in Russian noun inflection. In: O. Arnaudova, W. Browne, M. L. Rivero and D. Stojanović (eds). Proceedings of Formal Approaches to Slavic Linguistics 12.

Muysken, P. 1997. Callahuaya. In: S.G. Thomasan (ed.) Contact languages. Amsterdam: Benjamins. 427-48. 
Neidle, Carol J. 1988. The role of case in Russian syntax. Dordrecht, Boston: Kluwer Academic Publishers.

Nikolaeva, I. and M. Tolskaya. 2001. A grammar of Udihe. Berlin: Berlin: Mouton de Gruyter.

Noreen, A. 1923. Altisländische und altnorwegische Grammatik. Halle: M. Niemeyer.

Noyer, R. 1997. Features, positions and affixes in autonomous morphological structure. New York and London: Garland.

Noyer, R. 1998. Impoverishment theory and morphosyntactic markedness. . In: S.G. Lapointe, D.K. Brentari, and P.M. Farrell (eds), Morphology and its relation to phonology and syntax. Stanford: CSLI Publications. 264-85.

Nussbaum, L. V., W. W. Gage and D. Varre. 1970. Dakar Wolof: a basic course. Washington, D.C.: Center for Applied Linguistics.

Reesink, G. (ed.). 2002. Languages of the eastern Bird's Head. Canberra: Australian National University.

Rice, K. 1989. A grammar of Slave. Berlin: Mouton de Gruyter.

Sasse, H. 1976. Dasenech. In: M. L. Bender (ed.) The non-Semitic languages of Ethiopia. East Lansing: African Studies Center, Michigan State University. 196221.

Sridhar, S. N. 1989. Kannada. London: Routledge.

Stump, G. T. 1993. On rules of referral. Language 69/3. 449-479.

Stump, G. T. 2001. Inflectional morphology. Cambridge: Cambridge University Press.

Sunik, O. P. 1997. Udègejskij jazyk. In: Jazyki mira; mongol'skie jazyki, tungusoman'čžurskie jazyki, japonskij jazyk, korejskij jazyk. Moscow: Indrik. 236-48

Szemerenyi, O. 1989. Einführung in die vergleichende Sprachwissenchaft. Darmstadt: Wissenschaftliche Buchgesellschaft.

Tosco, M. 2001. The Dhaasanac language. Köln: Rüdiger Köppe.

Turton, D. 1981. Le Mun (Mursi). In: G. Manessy (ed.) Les langues de l'Afrique subsaharienne (Le langues dans le monde ancien et moderne, vol. 1.1). Paris. Éditions du CNRS. 335-50.

Upadhyaya, U. P. 1976. A comparative study of Kannada dialects: Bellary, Gulbarga, Kumta, and Nanjangud dialects. Mysore: Prasaranga, University of Mysore.

Viitso, T.-R. 1998. Fennic. In: D. Abondolo (ed.) The Uralic languages. London: Routledge. 96-114.

Voorhoeve, C.L. 1975. Central and Western Trans-New Guinea phylum languages. In: S. A. Wurm (ed.) Papuan Languages and the New Guinea linguistic scene (Pacific Linguistics C38). Canberra: Australian National University. 345-459.

Wegera, K.-P. 2000. Morphologie des Frühneuhochdeutschen. In: W. Besch, O. Reichmann and S. Sonderegger (eds) Sprachgeschichte. Ein Handbuch zur Geschichte der deutschen Sprache und ihrer Erforschung [volume 1.2]. Berlin: Mouton de Gruyter. 1313-1322.

Werner, R. 1987. Grammatik des Nobiin (Nilnubisch). Hamburg: Helmut Buske Verlag.

Wiese, Bernd. 1996. Iconicity and syncretism. In: R. Sackmann (ed.) Theoretical linguistics and grammatical description: papers in honour of Hans-Heinrich Lieb on the occasion of his 60th birthday. Amsterdam: John Benjamins. 323-344.

Williams, E. 1994. Remarks on lexical knowledge. Lingua 92. 7-34.

Wilson, D. 1974. Suena Grammar (Workpapers in Papua New Guinea Languages 8). Ukarumpa, Papua New Guinea: Summer Institute of Linguistics. 
Zwicky, A. 1985. How to describe inflection. In: Proceedings of the eleventh annual meeting of the Berkeley Linguistics Society. 372-386. 